\title{
A CASE OF LITHIUM INDUCED NEPHROTOXICITY IN A 41 YEAR OLD WOMAN WITH BIPOLAR DISORDER
}

\author{
Aashish Bhagyanagar ${ }^{1}$, A. K. Badrinath ${ }^{2}$, K. Suresh ${ }^{3}$, Debranjani Chattopadhyay ${ }^{4}$
}

\section{HOW TO CITE THIS ARTICLE:}

Aashish Bhagyanagar, A. K. Badrinath, K. Suresh, Debranjani Chattopadhyay. "A Case of Lithium Induced Nephrotoxicity in a 41 Year Old Woman with Bipolar Disorder". Journal of Evolution of Medical and Dental Sciences 2014; Vol. 3, Issue 57, October 30; Page: 13034-13039, D0I: 10.14260/jemds/2014/3730

ABSTRACT: Many psychiatric drugs improve the quality of life and reduce morbidity significantly. In some rare cases, due to aberrant compliance or dependent behavior by the patient, misuse of the drug can cause systemic complications which far more serious than the initial presenting complaint. We report one such case of prolonged misuse of lithium by a patient which led to the rare complication of irreversible chronic kidney disease.

KEYWORDS: Lithium, nephrotoxicity, bipolar disorder, tremors.

INTRODUCTION: We report here a case of a patient who presented with tremors, ataxia, dyselectrolytemia and elevated renal parameters. Comprehensive history of the patient revealed that she was under treatment with Lithium for the past twenty years. Hence she had developed the very rare complication of Lithium induced chronic kidney disease. Her biochemical test showed substantially increased serum Lithium values, leukocytosis along with dyselectrolytemia. After Lithium correction was initiated, patient was symptomless and had improved lab parameters

Intake of psychiatric drugs is often overlooked by physicians while arriving at a diagnosis for patients suffering from other organic or systemic diseases. As several psychiatric drugs, especially when taken in higher doses can lead to severe systemic illness, it is imperative for physicians to take a detailed history of psychiatric condition medications which will enable the physician to make an accurate diagnosis and initiate an effective treatment.

CASE REPORT: A 48 year old female patient who is a house wife presented to us with complaints of sleeplessness, intermittent episodes of depression, tremors and grinding of teeth for the past one month. Patient was not taking feeds properly for past 1 week. The patient also complained of weakness of all four limbs and inability to walk for one day prior to admission.

On examination the patient was conscious and drowsy. Local examination showed resting tremors of all four limbs and nystagmus. The vitals were stable and the other organ systems appeared normal. Examination of the central nervous system showed that the cranial nerves were intact and spinomotor system examination showed hypotonia and a power of 3/5.

All her deep tendon reflexes were diminished and the plantar showed bilateral withdrawal response. A thorough history of past complaints showed that the patient was on treatment with lithium for the treatment of bipolar disorder for the past two years.

BLOOD INVESTIGATIONS: Complete blood picture showed leukocytosis while biochemical reports showed dyselectrolytemia and an increase of renal parameters. The biochemical investigations revealed reduced serum sodium and potassium levels and as trans-tubular potassium gradient was 4.4 , renal loss of electrolytes was suspected. Serum Lithium value was greatly elevated at $1.6 \mathrm{mmol} / \mathrm{l}$. 


\section{CASE REPORT}

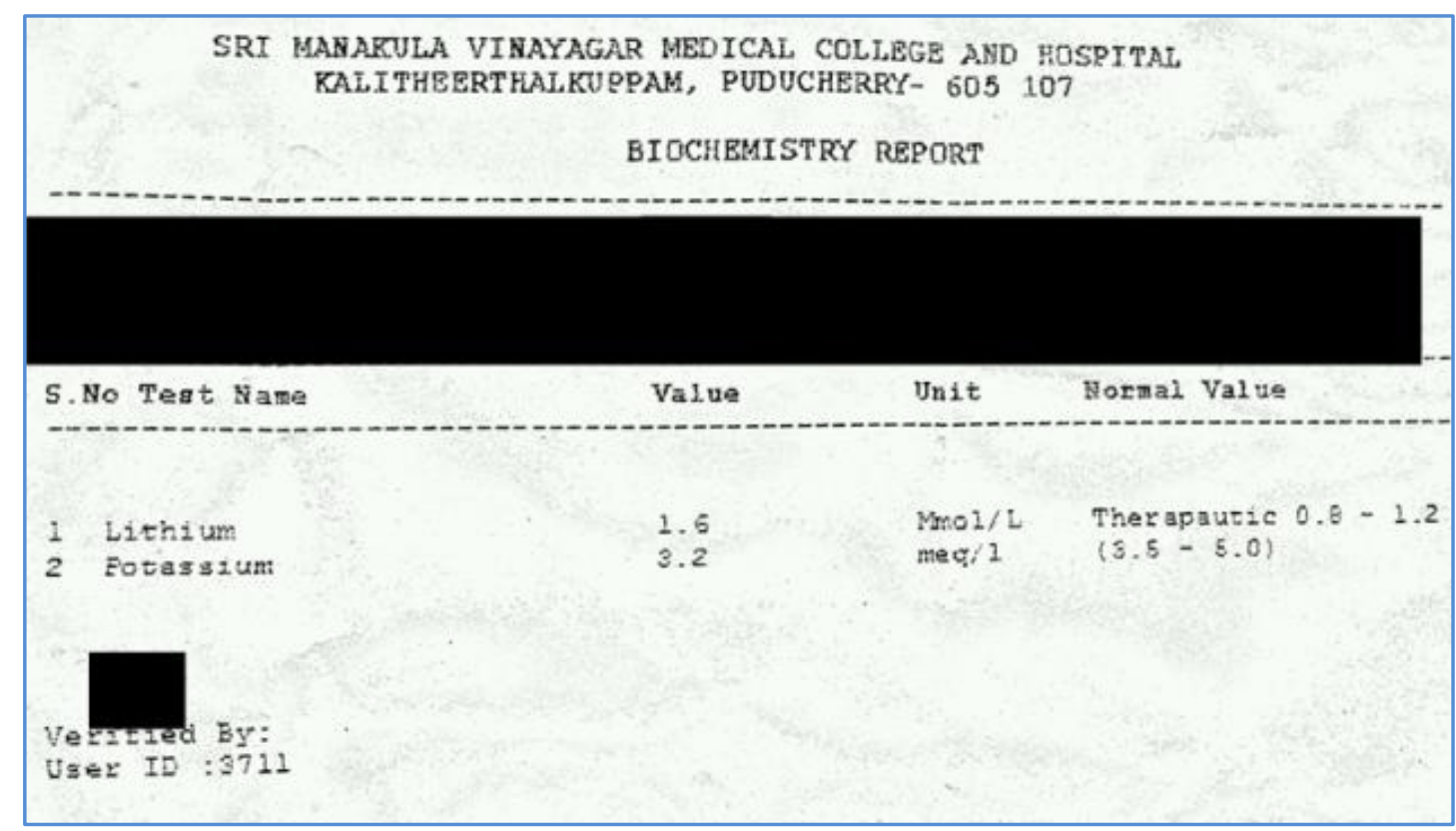

\section{Fig. 1: Lithium levels}

SRI MANAKULA VINAYAGAR MEDICAL COLLEGB AND HOSPITAL KALITHEERTHALKUPPAM, PUDUCHERRY- 605107

\section{BIOCHEMISTRY REPORT}

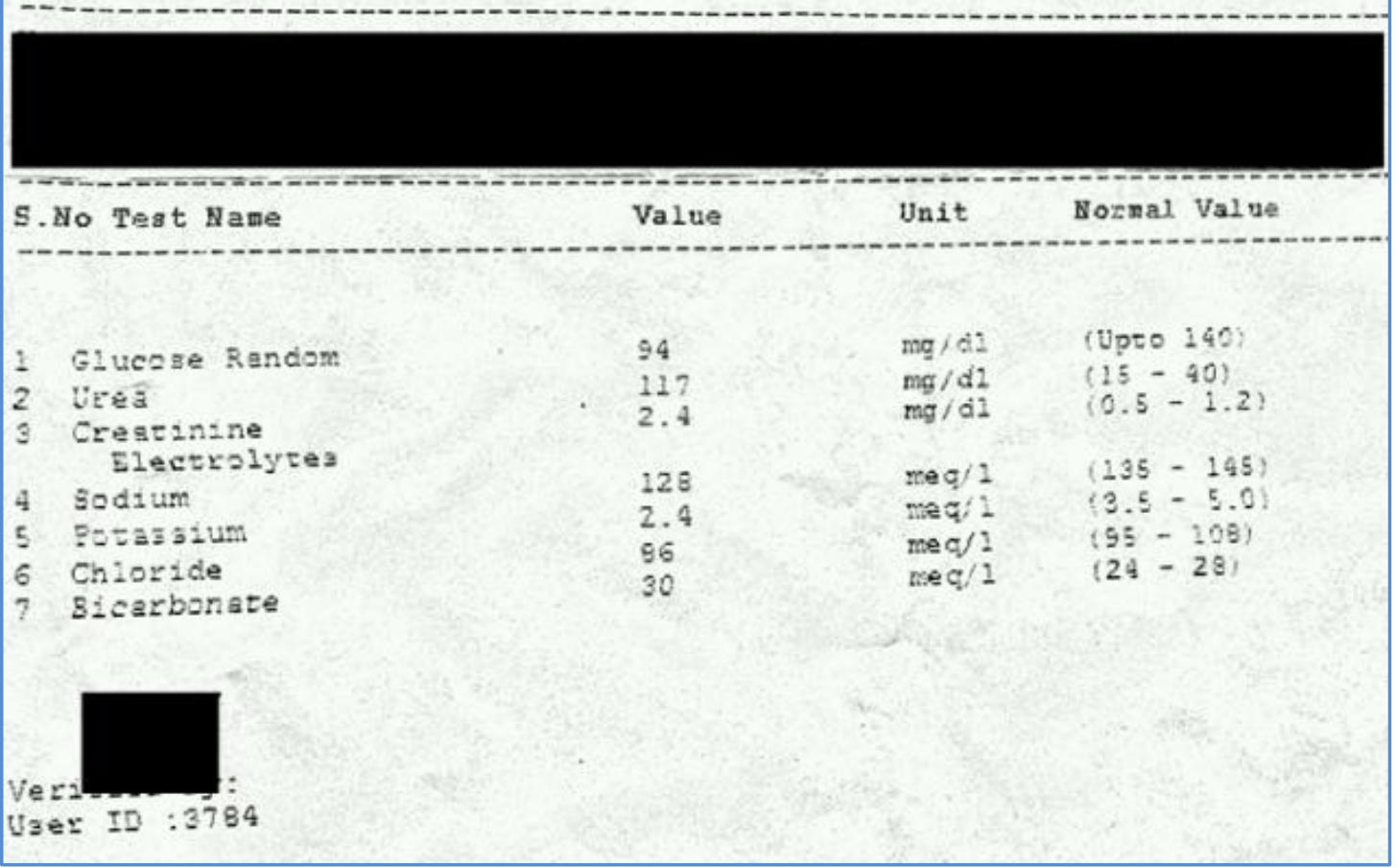

Fig. 2: Renal parameters and Serum electrolytes 


\section{CASE REPORT}

\begin{tabular}{|c|c|c|c|c|c|c|}
\hline Parameter & WBC & Neutrophils & Lymphocytes & RBC & Platelets & Haemoglobin \\
\hline Values & $\begin{array}{c}17,600 / \\
\mathrm{cu} \mathrm{mm}\end{array}$ & $82 \%$ & $14 \%$ & $\begin{array}{c}42.6 \text { lakhs/ } \\
\text { cu mm }\end{array}$ & $\begin{array}{c}5.28 \\
\text { lakhs/ } \\
\text { cu mm }\end{array}$ & $12.3 \mathrm{gms} / \mathrm{dl}$ \\
\hline \multicolumn{6}{|c|}{ Table 1: Complete blood picture } \\
\hline
\end{tabular}

\begin{tabular}{|c|c|c|c|c|}
\hline Parameters & Sr. Sodium & Sr. Potassium & Sr. Bicarbonate & Sr. Chloride \\
\hline Values & $128 \mathrm{meq} / \mathrm{l}$ & $2.4 \mathrm{meq} / \mathrm{l}$ & $30 \mathrm{meq} / \mathrm{l}$ & $86 \mathrm{meq} / \mathrm{l}$ \\
\hline
\end{tabular}

\begin{tabular}{|c|c|c|c|c|}
\hline Parameters & Sr. Lithium & Sr. Calcium & Sr. Uric acid & $\begin{array}{c}\text { Sr. } \\
\text { Phosphorous }\end{array}$ \\
\hline Values & $1.6 \mathrm{mmol} / \mathrm{l}$ & $8.2 \mathrm{mg} / \mathrm{dl}$ & $8.4 \mathrm{mg} / \mathrm{dl}$ & $3.5 \mathrm{mg} / \mathrm{dl}$ \\
\hline \multicolumn{5}{|c|}{ Table 2: Serum electrolytes } \\
\hline
\end{tabular}

\begin{tabular}{|c|c|c|c|c|c|c|c|c|c|}
\hline Parameters & Urea & Creatinine & $\begin{array}{c}\text { Spot } \\
\text { Sodium }\end{array}$ & $\begin{array}{c}\text { Spot } \\
\text { Potassium }\end{array}$ & $\begin{array}{c}\text { Spot } \\
\text { protein }\end{array}$ & Albumin & Sugars & $\begin{array}{l}\text { Pus } \\
\text { cells }\end{array}$ & RBC \\
\hline Values & $\begin{array}{c}117 \\
\mathrm{mg} / \mathrm{dl}\end{array}$ & $\begin{array}{c}2.4 \\
\mathrm{mg} / \mathrm{dl}\end{array}$ & $50.3 \mathrm{meq} / \mathrm{l}$ & $45.2 \mathrm{meq} / \mathrm{l}$ & $\begin{array}{c}71 \\
\mathrm{mg} \%\end{array}$ & + & Nil & $2-3$ & Nil \\
\hline
\end{tabular}

Table 3: Renal parameters

\begin{tabular}{|c|c|c|}
\hline Parameter & TSH & T4 \\
\hline Values & $1.3 \mathrm{mIU} / \mathrm{ml}$ & $1.2 \mathrm{ng} / \mathrm{ml}$ \\
\hline \multicolumn{2}{|c|}{ Table 4: Thyroid function tests } \\
\hline
\end{tabular}

Ultrasound of abdomen confirmed the presence of bilateral renal parenchymal disease, small sized kidney and showed increased parenchymal echoes.

Fig. 3: Ultrasound images showing chronic kidney disease in left and right kidney respectively.
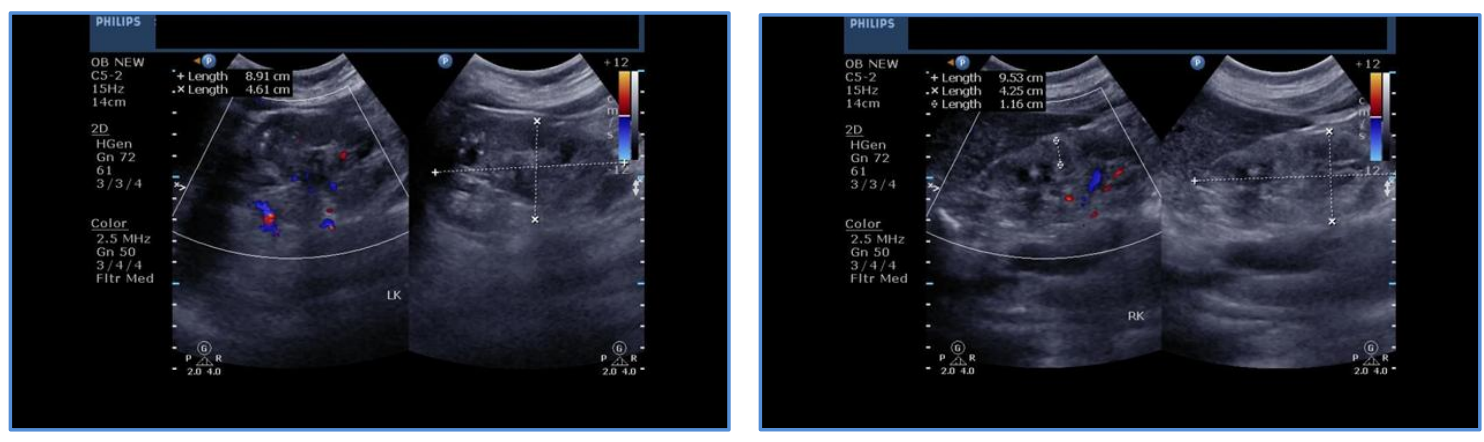

\section{Fig. 3}


Fig. 4: ECG -'U' waves characteristic of hypokalaemia

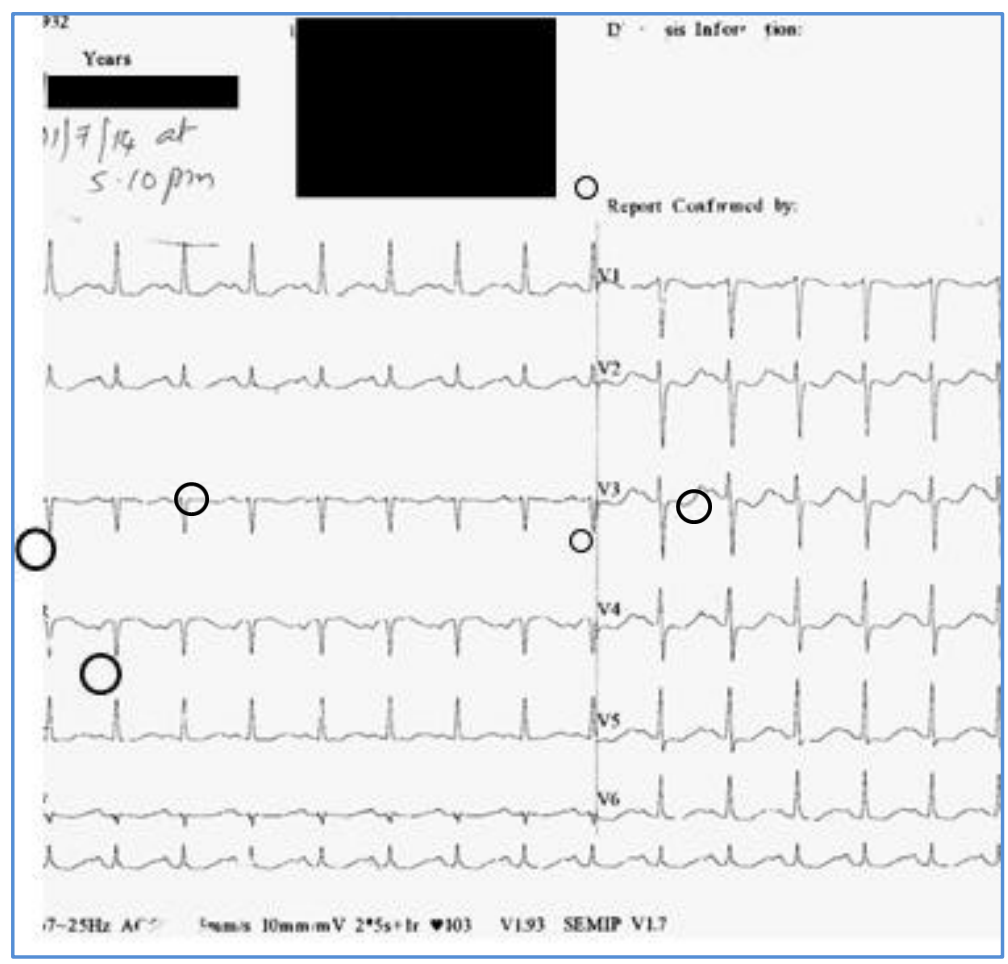

\section{Fig. 4}

Upon discontinuation of lithium and other electrolyte correction, the patient showed gradual but considerable reduction of symptoms. Biochemical analysis showed a correction of lithium, sodium and potassium. The patient was symptomless after one week. After a psychiatric review she was started on Quetiapine and Divalproex as an alternative to lithium for the treatment of her bipolar disorder

DISCUSSION: Lithium is an effective drug in patients with recurrent bipolar disorder type 1 and is used as an anti-suicidal and neuro-protective drug. However it has a very narrow therapeutic window therefore meticulous monitoring of its serum levels is essential.

Though the mechanism of action of lithium is not completely understood, the following theories have found widespread acceptance:

1. Lithium partly replaces body sodium is nearly equally distributed inside and outside the body cells.

This may affect the ionic fluxes across brain cells and modify the conduction property of cellular membranes.

2. Lithium has been found to decrease the release of noradrenaline and dopamine in the brain of treated animals without affecting 5-HT release. This may correct any imbalance in the turnover of brain monoamines.

As far as other systems are concerned, Lithium inhibits the action of ADH on distal tubules and cause diabetes insipidus-like state. It has some insulin-like action on glucose metabolism. 
Leucocyte count is increased by lithium therapy. Lithium reduces thyroxine synthesis by interfering with iodination of tyrosine.

\section{DRUG INTERACTIONS OF LITHIUM:}

1. Loop and thiazide diuretics.

2. NSAIDS.

3. Busipirone.

4. Opioids like Pethidine, Tramadol, Oxycodone and fentanyl.

5. Antidopiminergic agents.

6. ACE-inhibitors. ${ }^{1}$

SIDE EFFECTS, OVERDOSE AND TOXICITY OF LITHIUM: Lithium may cause constitutional symptoms such as;

- Headache.

- Amnesia.

- Nausea and vomiting.

- Confusion.

- Hair loss/thinning.

\section{HAZARDOUS SIGNS:}

- Tremors.

- Ataxia.

- Dysarthria.

- Nystagmus.

- Convulsions.

- Renal impairment (rare). ${ }^{2}$

Many severely poisoned patients can develop a syndrome of irreversible lithium-effectuated neurotoxicity (SILENT) ${ }^{3}$ such as cognitive impairment, sensorimotor peripheral neuropathy, and cerebellar dysfunction.

FATAL DOSE: Over dosage, usually with plasma concentrations of greater than $1.5 \mathrm{mmol} / \mathrm{l}$ of lithium may cause serious toxicity and a concentration of greater than $2.5 \mathrm{mmol} / \mathrm{l}$ is usually fatal. ${ }^{4}$

DIAGNOSIS: The estimation of serum lithium concentration along with a thorough clinical examination with an emphasis on looking for hazardous signs of toxicity remains the cornerstones of diagnosis.

\section{TREATMENT:}

- Immediate stoppage of Lithium along with initiation of therapy with substitutes to combat psychiatric exacerbations.

- Symptomatic treatment of constitutional symptoms.

- Corrections of electrolyte imbalance if present. 
- Treatment of hypothyroidism if present.

- Treatment of any neurological and renal disorders if present.

\section{ALTERNATIVES TO LITHIUM:}

1. Carbamazepine.

2. Sodium Valproate.

3. Lamotrigine.

4. Topiramate.

Atypical antipsychotics like Olanzapine, Risperidone and newer atypical antipsychotics; Aripiprazole, Quetiapine and Divalproex are now the first line drugs for control of acute mania.

\section{REFERENCES:}

1. Markowitz GS, Radhakrishanan J, Kambham N, Valeri AM, Hines WH, D'agati VD; Lithium Nephrotoxicity: A Progressive Combined Glomerular and Tubulo interstitial Nephropathy; J Am SocNephrol 11: 1439-1448, 2000.

2. Claire P, Fadi F, Laure-Hélène N, Bénédicte $S$, Christian E, Henri K, Françoise $M$ and Jean-Pierre G; Lithium-induced nephropathy: Rate of progression and prognostic factors; Kidney International (2003) 64, 585-592.

3. Chan WY, P Mosca, Rennert OM; Lithium nephrotoxicity: a review;Ann Clin Lab Sci July 1, 1981; 11 (4) :343-349.

4. Sarah MM, James D, Christopher BK; the Impact of Long-Term Lithium Treatment On Renal Function In An Outpatient Population; Ulster Med J. May 2008; 77 (2): 102-105.

\section{AUTHORS:}

1. Aashish Bhagyanagar

2. A. K. Badrinath

3. K. Suresh

4. Debranjani Chattopadhyay

\section{PARTICULARS OF CONTRIBUTORS:}

1. Resident, Department of General Medicine, Sri Manakula Vinayagar Medical College and Hospital, Pondicherry.

2. Professor \& HOD, Department of General Medicine, Sri Manakula Vinayagar Medical College \& Hospital, Pondicherry.

3. Associate Professor, Department of General Medicine, Sri Manakula Vinayagar Medical College \& Hospital, Pondicherry.
4. Assistant Professor, Department of General Medicine, Sri Manakula Vinayagar Medical College \& Hospital, Pondicherry.

\section{NAME ADDRESS EMAIL ID OF THE} CORRESPONDING AUTHOR:

Dr. Aashish Bhagyanagar, Quarter \# 37, Assistant Professors Quarters, Sri Manakula Vinaygar Medical College \& Hospital, KT Kuppam, Madagadipet, Pondicherry-605107.

Email: aashishbhagya@gmail.com

Date of Submission: 14/10/2014. Date of Peer Review: 15/10/2014. Date of Acceptance: 28/10/2014. Date of Publishing: 30/10/2014. 